\title{
Research Letter \\ Seychelles Lagoon Provides Corals with a Refuge from Bleaching
}

\author{
David Iluz, ${ }^{1}$ Razi Vago, ${ }^{2}$ Nanette E. Chadwick, ${ }^{1,3,4}$ Razi Hoffman, ${ }^{1}$ and Zvy Dubinsky ${ }^{1}$ \\ ${ }^{1}$ The Mina and Everard Goodman Faculty of Life Sciences, Bar-Ilan University, Ramat-Gan 52900, Israel \\ ${ }^{2}$ Department of Biotechnological and Environmental Engineering and Institute for Applied Biosciences, \\ Ben-Gurion University of the Negev, Beer Sheva 84105, Israel \\ ${ }^{3}$ Department of Biological Sciences, 101 Rouse Life Sciences Building, Auburn University, Auburn, AL 36849, USA \\ ${ }^{4}$ Interuniversity Institute for Marine Sciences, P.O. Box 469, Eilat 88103, Israel
}

Correspondence should be addressed to David Iluz, iluzda@mail.biu.ac.il

Received 30 December 2007; Accepted 14 May 2008

Recommended by Susan Bell

\begin{abstract}
An extensive bleaching event in the summer of the year 1997-1998 affected most reefs along East Africa's shores. In the aftermath of that episode, the reefs of Île Alphonse in the Seychelles were examined and it was found that reefs along the seaward slopes of the island lost $>95 \%$ of their branching coral colonies, with considerably higher survival of massive species. Île Alphonse features a nearly circular shallow lagoon, with steep seaward slopes. Contrary to our expectations, mortality in the warmer lagoon was far lower than of coral colonies on the surrounding slopes, bathed in deeper and cooler waters. We suggest that corals in the lagoon were protected from UV radiation by leachate stemming from seagrass leaves steeped in the lagoon. Our measurements in the lagoon showed a strong attenuation of ultraviolet radiation, not observed in the waters outside the lagoon, and laboratory examination confirmed that the strong UV absorption of substances leached into seawater from decomposing leaves of the seagrass Thalassodendron (=Cymodocea) testudinaceum. Our findings demonstrate the synergism between elevated seawater temperature and UV radiation in triggering bleaching on shallow reefs.
\end{abstract}

Copyright (c) 2008 David Iluz et al. This is an open access article distributed under the Creative Commons Attribution License, which permits unrestricted use, distribution, and reproduction in any medium, provided the original work is properly cited.

Global warming, possibly accompanied by increased UV radiation and oceanic acidification [1], is a likely culprit in the recent worldwide decline of coral reefs. The coral bleaching event of 1997-1998, which spread throughout the Indian Ocean, Southeast Asia, the Caribbean, and parts of the far eastern and western Pacific, is probably the most severe such episode in recorded history [2, 3]. Recent field and laboratory studies have demonstrated that elevated seawater temperatures can indeed induce bleaching in corals [4-7].

While documenting an extensive mortality episode that struck East Africa's coral reefs, we found that, contrary to our expectations, corals on the seaward slopes of a small cay in the Seychelles were the hardest hit, whereas colonies in a warm and turbid lagoon fared much better.

The data for the study were collected in November 1998 during an expedition to Île Alphonse, a coral cay four nautical miles in diameter in the Seychelles archipelago (see Figure 1). Data were collected by SCUBA diving as video transects, which were subsequently analyzed with image processing software. Analysis of live coral colonies and recentlybleached coral skeletons indicated that, prior to the 19971998 bleaching event, the percent cover of live massive stony corals was much higher than that of branching corals inside the lagoon, while the reverse pattern occurred on the outer reef slope (see Figure 2(a)). In contrast, after the bleaching event, most corals of both growth forms survived within the lagoon, while especially the branching corals suffered extensive mortality on the outer reef slope, leading to very low live coral cover (see Figure 2(b)). On the outer reef slope, the mortality of branching colonies reached 100\% near the surface, whereas among the massive corals, mortality was about $20 \%$ at all depths (see Figure 2(c)). Many of the massive colonies were only partially affected and, in such cases, only their upward-facing portions were bleached. Our observations are in agreement with recent reports that coral colonies in Phuket have been, in many cases, only partially affected [8]. However, there the differences 


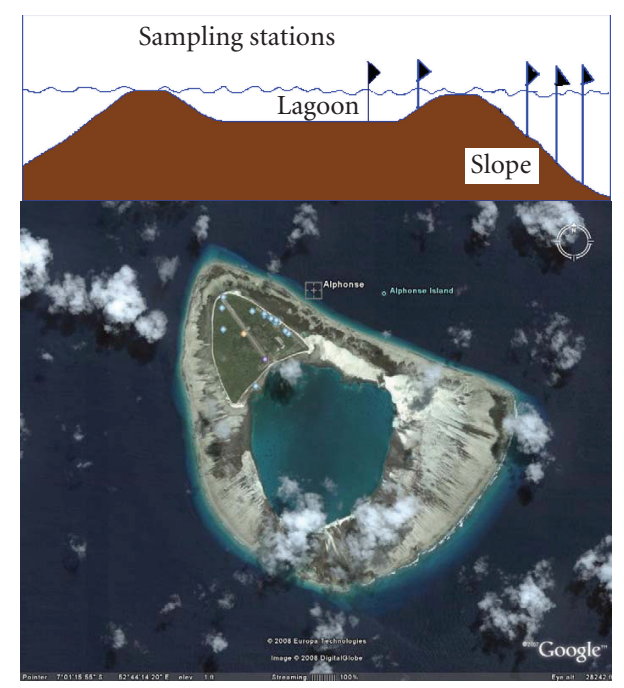

FIgURE 1: The Île Alfonse lagoon: (a) schematic transects, (b) aerial view.

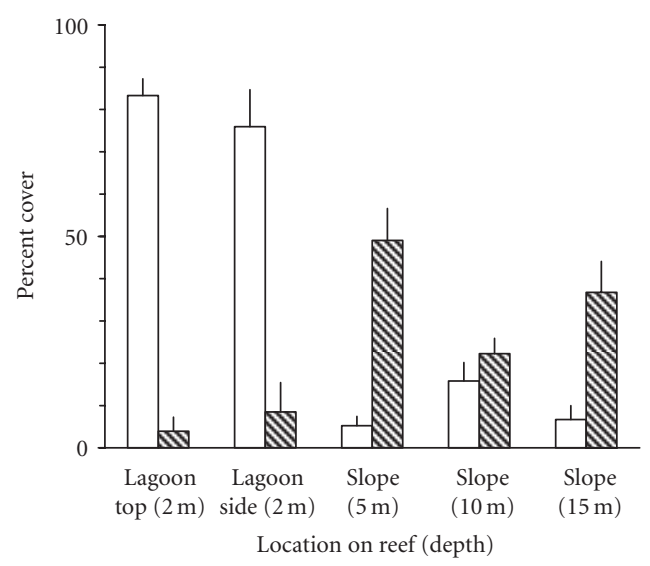

(a) Before bleaching

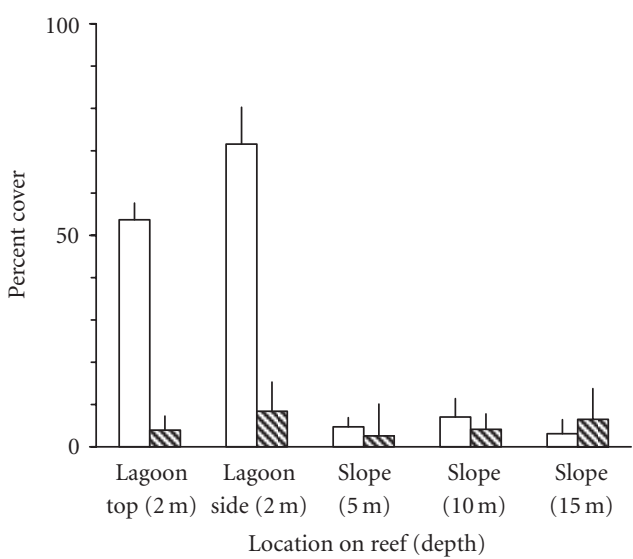

(b) After bleaching

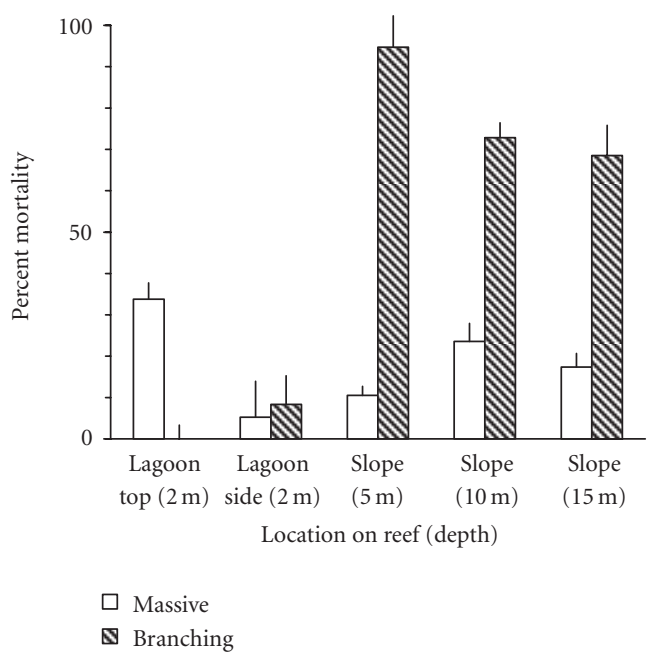

(c) Percent change

FIGURE 2: Stony coral percent cover and mortality at Ile Alphonse, Seychelles, surrounding the 1997-1998 bleaching episode. Comparison of massive and branching colonies inside the lagoon and on the outer reef slope. (a) Percent cover of live stony corals prior to the bleaching episode, from analysis of live coral colonies and recently-bleached coral skeletons that appeared to have died within the year preceding. (b) Percent cover of live stony corals after the bleaching episode. (c) Mortality rates following the bleaching episode. "Lagoon top" refers to corals on the top of shallow reef patches inside the lagoon, and "lagoon side" refers to corals on the vertical sides of reef patches in the lagoon. Data were collected during November 1998, from $1-\mathrm{m}^{2}$ digitized video quadrates $(N=12-39)$ at each location. 


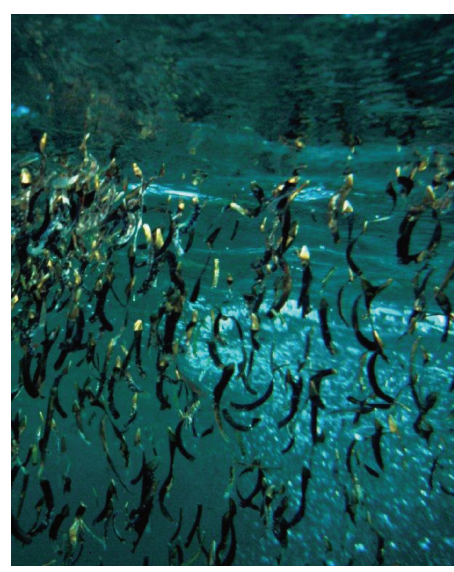

Figure 3: The Ile Alphonse lagoon. Leaves of the seagrass Thalassodendron testudinum leaching colored substances.

in bleaching resulted from exposure to high light rather than UV radiation, and previous exposure to solar bleaching protected colony faces from subsequent thermal bleaching.

Our attention was drawn to the striking and counterintuitive differences in coral fate between the turbid and warm $\left(35^{\circ} \mathrm{C}\right)$ lagoon and the clearer, cooler $\left(28^{\circ} \mathrm{C}\right)$ outerreef slope. All along the lagoon shore, we noticed a huge accumulation of drying leaves of the seagrass Thalassodendron (=Cymodocea) testudinaceum. Visible amounts of colored substances were being leached into the lagoon water out of this decomposing mass of sea grass (see Figure 3). Underwater light measurements were carried out using a submersion spectroradiometer (Li Cor-1800UW). Measurements were made in the lagoon which had a high content of leaves of the seagrass Thalassodendron (=Cymodocea) testudinaceum, and outside the lagoon there was no effect of these leaves. Upon examination of the spectral distribution of underwater irradiance, we found that the UV/PAR ratio was dramatically reduced in the lagoon (see Figure 4). Indeed, laboratory examination of Thalassodendron (=Cymodocea) testudinaceum leachate revealed a high absorption in UV range. The leaves were left to extract in Red Sea water at $25^{\circ} \mathrm{C}$ for 24 hours. The extract was scanned on a Varian 340 spectrophotometer in quartz cuvettes, with seawater as the reference (see Figure 5). This result is in agreement with the findings of Stabenau et al. [9] that the seagrass Thalassia testudinum releases a UV absorbing substance.

Our findings support previous reports [10] suggesting a synergistic effect of UV and temperature in triggering coral bleaching. Experiments have shown that an increase in UV light causes coral bleaching. UV light experienced by corals can increase in calm waters. The amount of mycosporinelike amino acids in a coral's tissues helps to determine how much UV it can withstand without bleaching $[11,12]$. In the case of Ile Alphonse, it is clear that the reduced mortality of corals in the lagoon was not related to reduced temperature or PAR levels but rather to a reduction of UV radiation in lagoonal waters. In general, it seems that in susceptible corals, bleaching may be triggered by synergism between high temperatures and other factors, whether UV, as at Ile

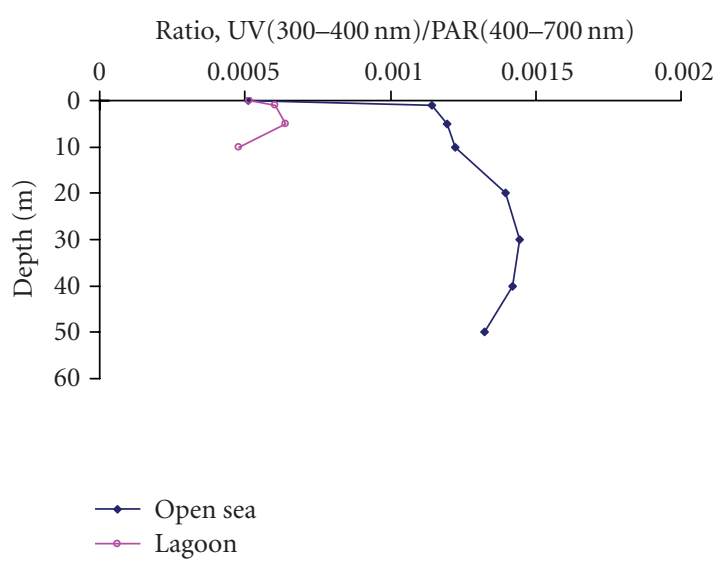

Figure 4: Comparison of photosynthetically available radiation, $400-700 \mathrm{~nm}$, (UV/PAR) ratio in the lagoon and on the outer reef slope, as measured with a LiCor-1800UW submersible spectroradiometer.

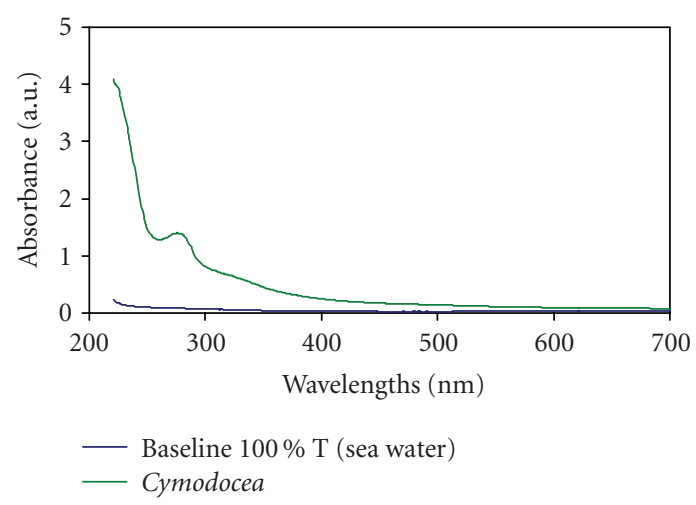

Figure 5: Absorbance spectrum of the leaf extraction of seagrass Thalassodendron (= Cymodocea) testudinum.

Alphonse, or high visible-light insolation. We hypothesize that, although temperatures in the lagoon exceeded those on the outer slope $\left(28^{\circ} \mathrm{C}\right)$, seagrass leachate rich in UVabsorbing compounds created an effective UV-blocking filter in lagoonal waters, thereby mitigating bleaching-inducing temperature effects. However, based on our data we cannot exclude the possibility that zooxanthellae clades with higher thermal tolerance may be involved. In such case that would confer additional protection from bleaching on the coral colonies in the lagoon, above that provided by the "UV filter" we report here. It has been suggested that some clades have higher thresholds for bleaching than others [13-15]. We suggest that this UV screening phenomenon, together with long-term adaptive mechanisms developed by lagoonal colonies exposed to higher temperatures, protected this population throughout the 1997-1998 bleaching event. The coral populations that survive in such protected refuges may be a source of propagules for future reef recovery.

\section{ACKNOWLEDGMENTS}

This research was made possible by an expedition to the Seychelle Islands sponsored by the Interuniversity Institute 
for Marine Science in Eilat, Israel. We thank the former managing director, Dr. Avi Baranes, for logistical and financial support. This research was supported by NATOSfP-981883 and Beit Berl College.

\section{REFERENCES}

[1] M. Fine and D. Tchernov, "Scleractinian coral species survive and recover from decalcification," Science, vol. 315, no. 5820, p. 1811, 2007.

[2] C. R. Wilkinson, Status of Coral Reefs of the World, Australian Institute of Marine Science, Townsville, Australia, 1998.

[3] T. Spencer, K. A. Teleki, C. Bradshaw, and M. D. Spalding, "Coral bleaching in the southern Seychelles during the 19971998 Indian Ocean warm event," Marine Pollution Bulletin, vol. 40, no. 7, pp. 569-586, 2000.

[4] P. L. Jokiel, "Solar ultraviolet radiation and coral reef epifauna," Science, vol. 207, no. 4435, pp. 1069-1071, 1980.

[5] B. E. Brown, M. D. A. Le Tissier, and J. C. Bythell, "Mechanisms of bleaching deduced from histological studies of reef corals sampled during a natural bleaching event," Marine Biology, vol. 122, no. 4, pp. 655-663, 1995.

[6] C. B. Cook, A. Logan, J. Ward, B. Luckhurst, and C. J. Berg Jr., "Elevated temperatures and bleaching on a high latitude coral reef: the 1988 Bermuda event," Coral Reefs, vol. 9, no. 1, pp. 45-49, 1990.

[7] P. W. Glynn and L. D'Croz, “Experimental evidence for high temperature stress as the cause of El Niño-coincident coral mortality," Coral Reefs, vol. 8, no. 4, pp. 181-191, 1990.

[8] B. E. Brown, R. P. Dunne, M. S. Goodson, and A. E. Douglas, "Marine ecology: bleaching patterns in reef corals," Nature, vol. 404, no. 6774, pp. 142-143, 2000.

[9] E. R. Stabenau, R. G. Zepp, E. Bartels, and R. G. Zika, "Role of the seagrass Thalassia testudinum as a source of chromophoric dissolved organic matter in coastal south Florida," Marine Ecology Progress Series, vol. 282, pp. 59-72, 2004.

[10] M. P. Lesser, "Elevated temperatures and ultraviolet radiation cause oxidative stress and inhibit photosynthesis in symbiotic dinoflagellates," Limnology and Oceanography, vol. 41, no. 2, pp. 271-283, 1996.

[11] D. F. Gleason, "Differential effects of ultraviolet radiation on green and brown morphs of the Caribbean coral Porites astreoides," Limnology and Oceanography, vol. 38, no. 7, pp. 1452-1463, 1993.

[12] S. Anderson, R. G. Zepp, J. Machula, D. Santavy, L. Hansen, and E. Mueller, "Indicators of UV exposure in corals and their relevance to global climate change and coral bleaching," Human and Ecological Risk Assessment, vol. 7, no. 5, pp. 12711282, 2001.

[13] S. Karako-Lampert, D. J. Katcoff, Y. Achituv, Z. Dubinsky, and N. Stambler, "Responses of Symbiodinium microadriaticum clade B to different environmental conditions," Journal of Experimental Marine Biology and Ecology, vol. 318, no. 1, pp. 11-20, 2005.

[14] A. C. Baker, "Flexibility and specificity in coral-algal symbiosis: diversity, ecology, and biogeography of Symbiodinium," Annual Review of Ecology, Evolution, and Systematics, vol. 34, pp. 661-689, 2003.

[15] K. E. Fabricius, J. C. Mieog, P. L. Colin, D. Idip, and M. J. H. Van Oppen, "Identity and diversity of coral endosymbionts (zooxanthellae) from three Palauan reefs with contrasting bleaching, temperature and shading histories," Molecular Ecology, vol. 13, no. 8, pp. 2445-2458, 2004. 

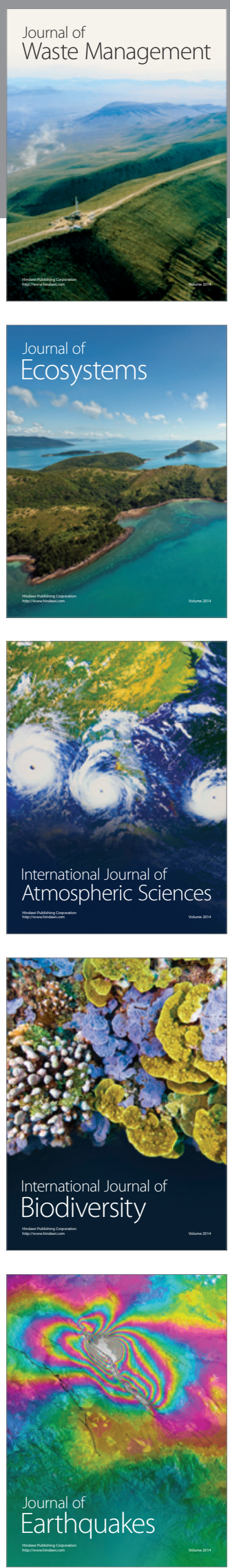
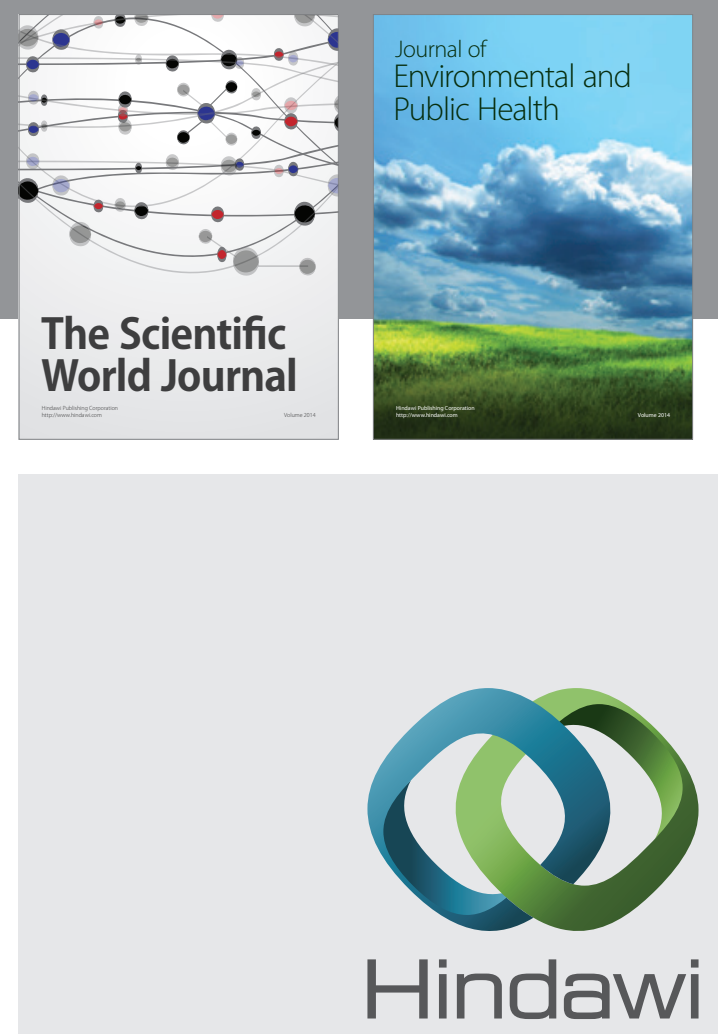

Submit your manuscripts at

http://www.hindawi.com
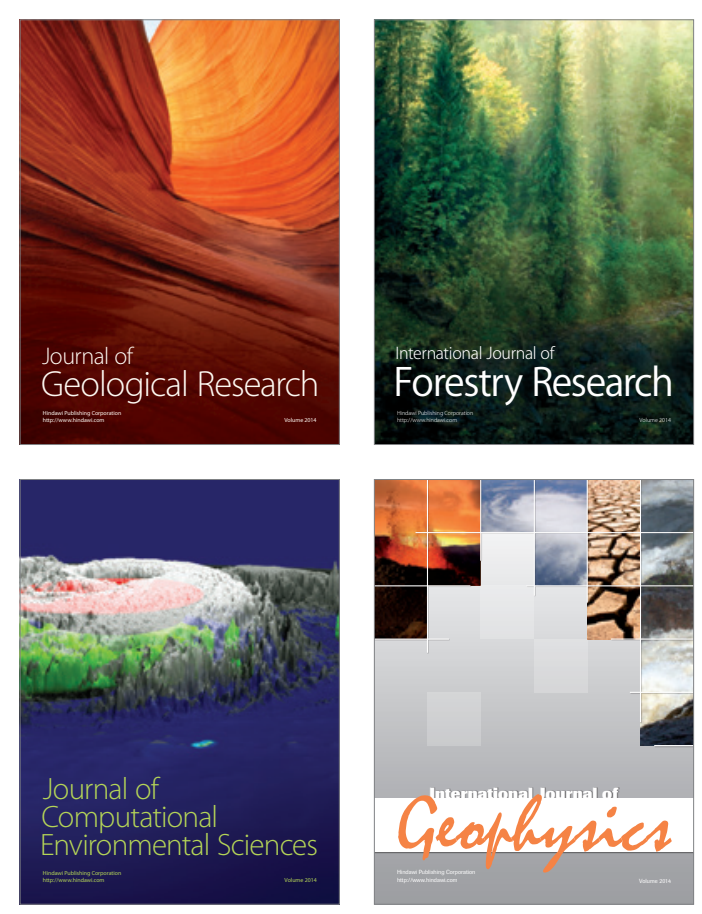
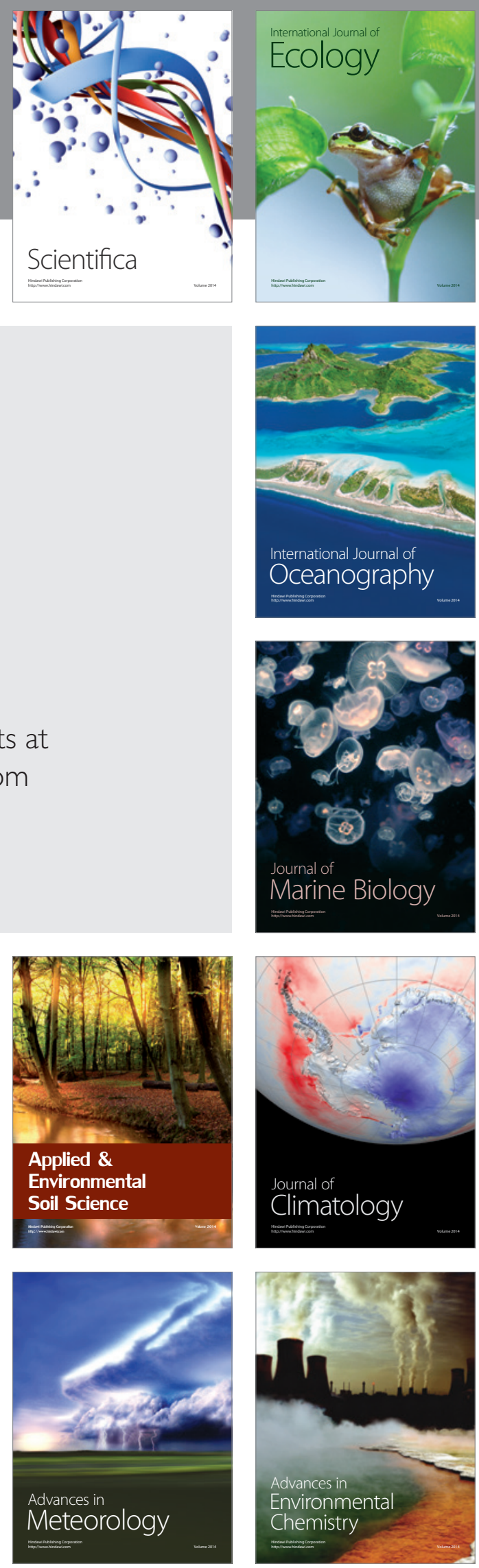